\title{
Teaching project: a low-cost swine model for chest tube insertion training
}

\section{Projeto de ensino: modelo suíno de baixo custo para treinamento de drenagem torácica}

Fernando Antonio Campelo Spencer Netto'; Camila Garcia Sommer²; Michael de Mello Constantino²; Michel Cardoso²; Raphael Flávio Fachini Cipriani²; Renan Augusto Pereira²

A B S T R A C T

\begin{abstract}
Objective: to describe and evaluate the acceptance of a low-cost chest tube insertion porcine model in a medical education project in the southwest of Paraná, Brazil. Methods: we developed a low-cost and low technology porcine model for teaching chest tube insertion and used it in a teaching project. Medical trainees - students and residents - received theoretical instructions about the procedure and performed thoracic drainage in this porcine model. After performing the procedure, the participants filled a feedback questionnaire about the proposed experimental model. This study presents the model and analyzes the questionnaire responses. Results: seventy-nine medical trainees used and evaluated the model. The anatomical correlation between the porcine model and human anatomy was considered high and averaged $8.1 \pm 1.0$ among trainees. All study participants approved the low-cost porcine model for chest tube insertion. Conclusion: the presented low-cost porcine model for chest tube insertion training was feasible and had good acceptability among trainees. This model has potential use as a teaching tool in medical education.
\end{abstract}

Key words: Training Programs. Education, Medical. Thoracic Wall. Models, Animal. Swine.

\section{INTRODUCTION}

Sinterns imulators use represents a significant evolution in medical teaching ${ }^{1}$. Theiy are a useful tool in training of students and professionals, decreasing patients' risks ${ }^{2-4}$.

Chest tube insertion is a medical skill used frequently in urgent and life-threatening situations, particularly in trauma ${ }^{5}$. It is generally accepted that every physician should master this life-saving skill1,5,6.

The present article demonstrates a simple, low-cost and low technology porcine model, used in a teaching project for chest tube insertion training. Also, it analyzes its acceptance by medical students and residents from a medical university in southwest of Paraná State, Brazil.

\section{METHODS}

We carried on a teaching project using porcine models in resuscitation procedures training for last-year medical students and residents, from June 2013 to June 2014, at Universidade Estadual do Oeste do Paraná, Cascavel. As a part of this project, trainees filled a feedback questionnaire about the used model. The chest tube insertion porcine model is presented and the questionnaires used for its assessment are currently analyzed. Before starting the project, it was submitted and analyzed, obtaining institutional approval (Prograd CR 40119/2014).

\section{Teaching Project Steps}

Each session of this educational project included groups of about ten medical students or residents, and consisted of three steps: a) trainees attended a class on thoracic anatomy, thoracentesis procedures and closed thoracic drainage ${ }^{5}$; b) they then practiced thoracic drainage in the porcine model under supervision; and c) trainees were asked to fill out a model evaluation questionnaire (optional).

\section{Chest tube insertion porcine model}

We used a rack of porcine ribs, from skin to pleural space. Each porcine hemithorax was divided and resulted in two models. Each model trained approximately five students. The ribs racks were purchased in local food markets, appropriate for human consumption, according to sanitary rules.

1. Universidade Estadual do Oeste do Paraná (Unioeste), Foz do Iguaçu, PR, Brasil; 2. Hospital Universitário do Oeste do Paraná (HUOP), Cascavel, PR, Brasil. 
Each chest specimen was fixed to a fenestrated basin, placed upside down (Figure 1). The remaining materials used were from the Medical Skills Lab, obtained by donation, without cost.

Details about the model confection can be found at the link: https://www.youtube.com/watch?v $=$ CZKJEDP3gig. During the study, different trauma situations were simulated, such as traumatopneia and penetrating chest trauma.

\section{Questionnaire}

The evaluation questionnaire asked about the epidemiological aspects, previous training in the management of chest trauma, resuscitation procedures on the chest and adequacy of the model for training medical students and residents. Some of the answers were not objects of this study, but used in order to improve graduation educational opportunities.

Specifically, we requested evaluations of the overall quality of the model (robustness, ease of handling and tissue similarity criteria) and anatomical correlation (similarity to the expected anatomy in humans), both with scores ranging from 0 to 10 .

The questionnaire was prepared by the main author and was not previously validated.

All information obtained by the questionnaire were grouped into tables using a spreadsheet, and analyzed with averages and percentages. When comparing the subgroups of students and residents, the values were expressed as mean and standard deviation, and we performed unpaired Student's t and chi-square tests, as appropriate.

\section{Teaching Group}

Seventy medical students in their Emergency Department internship rotation and nine residents from Internal Medicine took part in this study after undergoing chest tube insertion training, from June 2013 to June 2014

\section{RESULTS}

The study group characteristics are described in Table 1. There was no refusal from students or residents to take part in the training or filling up the feedback questionnaire. Regarding the general quality of the used model, the mean score given by medical students was $8.7 \pm 0.9$ and the mean score given by medical residents was $9.5 \pm 0.7(p=0.01)$. The final general quality score was $8.8 \pm 0.9$. When comparing anatomic correlation with

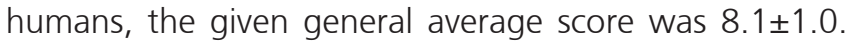
The scores for anatomical correlation given by residents were higher then the ones by medical students $(9.0 \pm 0.8$ vs. $8.0 \pm 1.0$ respectively; $p=0.005)$. All trainees approved the porcine model as an adjunct for training chest tube insertion.

\section{DISCUSSION}

Simulation is increasingly used in medical education ${ }^{1}$. Among the several available models, artificial simulation models have a relatively high initial cost and a low maintenance cost. In Brazil, the average cost of an artificial model for training of resuscitation procedures is between 10,000 and 12,000 American dollars. For comparison, in Brazilian ATLS centers using only artificial models in their courses, the cost for substitution of simulated skins and material reach in average US $\$ 200$ for 16 participants. In spite of the recent increase in artificial models for procedure training, the use of animal models is frequent, due to costs and higher handling similarity with human tissues when compared with synthetic materials ${ }^{7}$.

Live animal models have been used for a long time in medical education ${ }^{8,9}$. They require a series of maintenance costs related with animal care and ethical issues and may not be advantageous for basic procedures. Use of human cadavers requires ethical considerations and
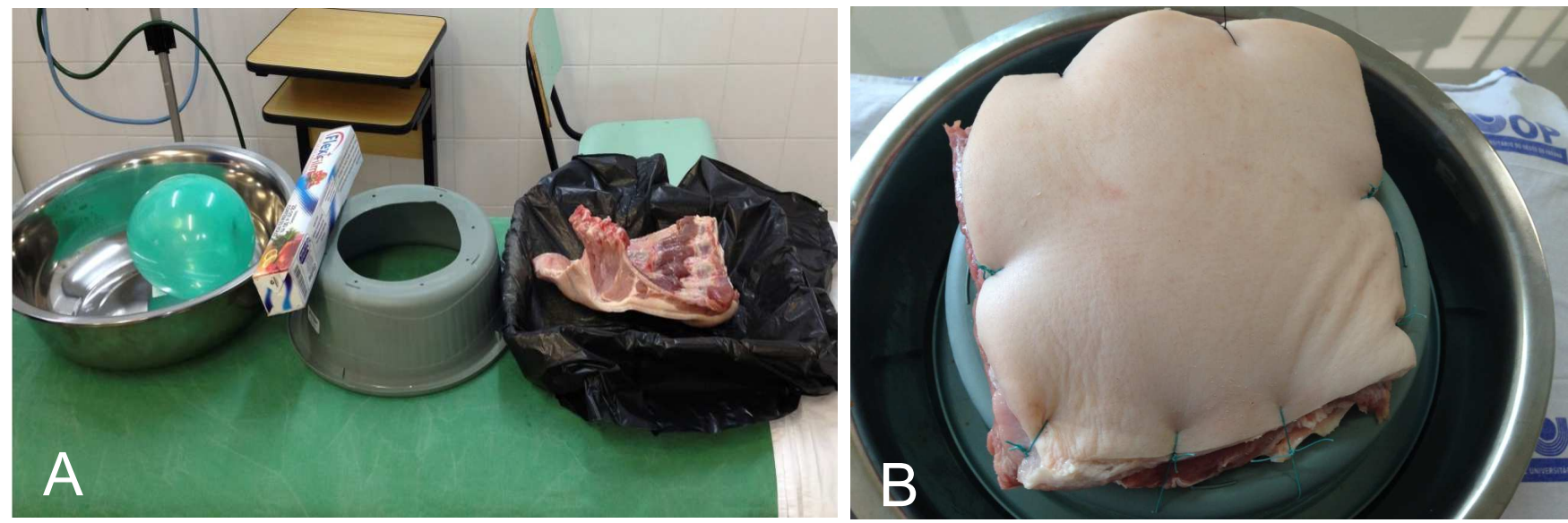

Figure 1 - Materials applyed and porcine model ready for use. 
Table 1 - Demographics of the study group.

\begin{tabular}{|c|c|c|c|c|c|c|}
\hline \multirow{2}{*}{$\frac{\text { Characteristics }}{\text { Age }}$} & \multirow[t]{2}{*}{ Medical } & \multirow[t]{2}{*}{ Students } & \multicolumn{2}{|c|}{ Residents } & \multicolumn{2}{|c|}{ All Trainees } \\
\hline & & & & & & \\
\hline \multirow{2}{*}{\multicolumn{7}{|c|}{ Gender n (\%) }} \\
\hline & & & & & & \\
\hline Female & 35 & $(50 \%)$ & 8 & $(88.9 \%)$ & 43 & $(54.4 \%)$ \\
\hline Male & 35 & $(50 \%)$ & 1 & $(11.1 \%)$ & 36 & $(45.6 \%)$ \\
\hline \multicolumn{7}{|c|}{ Previous experience in CTIP n (\%) } \\
\hline None & 9 & $(12.8 \%)$ & 1 & $(11.1 \%)$ & 10 & $(12.6 \%)$ \\
\hline 1-5 CTIPs & 51 & $(73 \%)$ & 3 & $(33.4 \%)$ & 54 & $(68.5 \%)$ \\
\hline 6-10 CTIPS & 10 & $(14.2 \%)$ & 5 & $(55.5 \%)$ & 15 & $(18.9 \%)$ \\
\hline
\end{tabular}

CTIP: chest tube insertion procedure.

previous agreements among institutions ${ }^{10}$. Animal segments are cheaper and easier to obtain when compared to whole animal cadavers ${ }^{7}$.

As expected, the analysis of the anatomical correlation of this porcine chest model with human tissues was considered high ${ }^{11}$. Interestingly, the smaller but slightly more experient group of medical residents attributed higher scores at this criterion when compared with medical students. Even though most of the trainees $(87 \%)$ had previously participated in chest tube insertion procedures in human patients, they unanimously approved training in the presented model. It may have given the opportunity to review the procedure in a controlled environment.

There are several models using animal segments in training resuscitation skills and chest tube insertion ${ }^{11,12}$. The presented model is simple, reproducible and cheap.
Each training session (average of ten trainees divided in two models) had an average cost of US $\$ 15$, resulting in an average cost of less than two American dollars per trainee. Due to its simplicity and low cost, this model is attractive in the initial phases of medical training, particularly in centers where resources are limited.

\section{Limitations}

This teaching project was based in a porcine hemithorax, not bringing real anatomic difficulties as hematomas, rib fractures, obesity, pain when manipulating the injured chest, urgency scenario and so on.

The presented porcine model can be improved. Also, it can be tested and validate by physicians with expertise in chest tube insertion. This study was an early step in developing a simple and cheap instrument to be used in medical education.

\title{
RE S U M O
}

\begin{abstract}
Objetivo: descrever e avaliar a aceitação do modelo porcino de baixo custo para drenagem torácica em projeto de ensino médico no oeste do Paraná, Brasil. Métodos: um modelo suíno de baixa tecnologia e baixo custo foi desenvolvido em projeto de ensino de drenagem torácica. Alunos de Medicina e médicos residentes receberam instruções teóricas sobre o procedimento e realizaram a drenagem torácica no modelo porcino. Após realizarem o procedimento, os participantes responderam a um questionário sobre o modelo experimental proposto. Esse estudo apresenta o modelo e analisa as respostas ao questionário. Resultados: setenta e nove participantes usaram e avaliaram o modelo. A correlação anatômica entre o modelo porcino e a anatomia humana foi considerada alta com média de $8,1+1,0$. Todos os participantes aprovaram o modelo porcino de baixo custo para o ensino de drenagem torácica. Conclusão: o modelo porcino de baixo custo para drenagem torácica apresentado neste projeto de ensino foi facilmente montado e teve boa aceitação local entre os participantes. Esse modelo tem potencial para ser usado como ferramenta de ensino na educação médica.
\end{abstract}

Descritores: Programas de Treinamento. Educação Médica. Parede Torácica. Modelos Animais. Suínos.

\section{REFERENCES}

1. Carter YM, Wilson BM, Hall E, Marshall MB. Multipurpose simulator for technical skill development in thoracic surgery. J Surg Res. 2010;163(2):186-91.
2. Fanning RM, Gaba DM. The role of debriefing in simulation-based learning. Simul Healthc. 2007;2(2):115-25.

3. Sergeev I, Lipsky AM, Ganor O, Lending G, Abebe-Campino G, Morose $A$, et al. Training modalities and self-confidence building in performance of life-saving procedures. Mil Med. 2007;177(8):901-6. 
4. Ziv Stephen D Small Paul Root Wolpe A. Patient safety and simulation-based medical education. Med Teach. 2000;22(5):48995.

5. Committee on Trauma, American College of Surgeons. ATLS: Advanced Trauma Liffe Support Program for Doctors. 8th ed. Chicago: American College of Surgeons; 2008.

6. Remes V, Sinisaari I, Harjula A, Helenius I. Emergency procedure skills of graduating medical doctors. Med Teach. 2003;25(2):14954.

7. Cho J, Kang GH, Kim EC, Oh YM, Choi HJ, Im TH, et al. Comparison of manikin versus porcine models in cricothyrotomy procedure training. Emerg Med J. 2008;25(11):732-4.

8. Flato UAP, Guimarães HP. Educação baseada em simulação em medicina de urgência e emergência: a arte imita a vida. Rev Soc Bras Clín Méd. 2011;9(5):360-4.

9. Olshaker JS, Brown CK, Arthur DC, Tek D. Animal procedure laboratory surveys: use of the animal laboratory to improve physician confidence and ability. J Emerg Med. 1989;7(6):593-7.
10. Proano L, Jagminas L, Homan CS, Reinert S. Evaluation of a teaching laboratory using a cadaver model for tube thoracostomy (1). J Emerg Med. 2002;23(1):89-95.

11. Naicker TR, Hughes EA, McLeod DT. Validation of a novel resinporcine thorax model for chest drain insertion training. Clin Med. 2012;12(1):49-52.

12. Ching JA, Wachtel TL. A simple device to teach tube thoracostomy. J Trauma. 2011;70(6):1564-7.

Received in: 09/05/2015

Accepted for publication: 18/12/2015

Conflict of interest: none.

Source of funding: none.

\section{Mailing address:}

Fernando Antonio Campelo Spencer Netto

E-mail: fspencernetto@gmail.com 